\title{
MONUMENT OF LUDOVICO ARIOSTO IN FERRARA, ITALY: CONSERVATION OF ARCHITECTURAL SURFACES AND STRUCTURAL CONSOLIDATION
}

\author{
CLAUDIO MODENA ${ }^{1,2 *}$, BENEDETTA CAGLIOTI ${ }^{3} \&$ ELVIS CESCATTI $^{1,2 \dagger}$ \\ ${ }^{1}$ University of Padova, Italy \\ ${ }^{2}$ SM Ingegneria s.r.l., Italy \\ ${ }^{3}$ Studio di architettura Benedetta Caglioti, Italy
}

\begin{abstract}
The iconic Renaissance monument in Ferrara was requested by Duke Ercole I d'Este at the end of the 15th century for the "Piazza Nova" of the Erculean Addition. The project comprised an equestrian statue of the Duke positioned on two monolithic columns with a pedestal, capitals and trabeated system. The project was never completed except for the $10 \mathrm{~m}$ monolithic column, upon which statues of Pope Alexander VII (1675), Napoleon (1810) and, finally, Ludovico Ariosto (1833), the symbolic Ferrarese poet were placed. The project involves the removal of recent interventions which were structurally and aesthetically invasive: lowering the statue using a specially designed engineering technique; disassembling the 11 st components of the capital due to oxidisation of the metal connectors; replacing the oxidised parts with new connectors; controlled cleaning of the surfaces; integration with mortars made on-site with natural and sustainable materials. The purpose of this project is to restore the cleaner and safer Monument of Ludovico Ariosto to the community through a "critical restoration", based on historical knowledge.

Keywords: heritage management, heritage architecture and historical aspects, corrosion and material decay, management and assessment of heritage buildings.
\end{abstract}

\section{INTRODUCTION}

The Monument of Ludovico Ariosto, located in the centre of Piazza Ariostea in Ferrara, is composed of two large steps, a pedestal, a monolithic column and the statue of the poet placed on top, with a total height of $21.2 \mathrm{~m}$ (Fig. 1). The restoration project of this Monument, commissioned by the Municipality of Ferrara, involved the conservation of various stone surfaces and structural consolidation.

\section{HISTORY OF THE MONUMENT OF LUDOVICO ARIOSTO}

Today's Piazza Ariostea was known as "Piazza Nova" of the Erculean Addition, important urban expansion of the city of Ferrara, begun at the end of the 15th century by the Duke Ercole I d'Este (1471-1505). Thank to this expansion called "Addizione Erculea" the city of Ferrara has been considered by scholars the first modern city of Europe, due to the social, economic, and dimensional reason of the project [1].

Erculean Addition is characterized by two main axes and the new square called "Piazza Nova". The Duke Ercole I d'Este planned his project to expand the built area of the medieval city to promote a huge economic campaign of real estate in order to help the political power to concentrate in only one place of the city the most important families of the Court. The importance of this operation is in the fact that it was the first time that a huge building campaign, with its complex urban implications, was carried out following an unitary project

\footnotetext{
* ORCID: https://orcid.org/0000-0001-7289-6879

$\dagger$ ORCID: https://orcid.org/0000-0003-3185-2321
} 


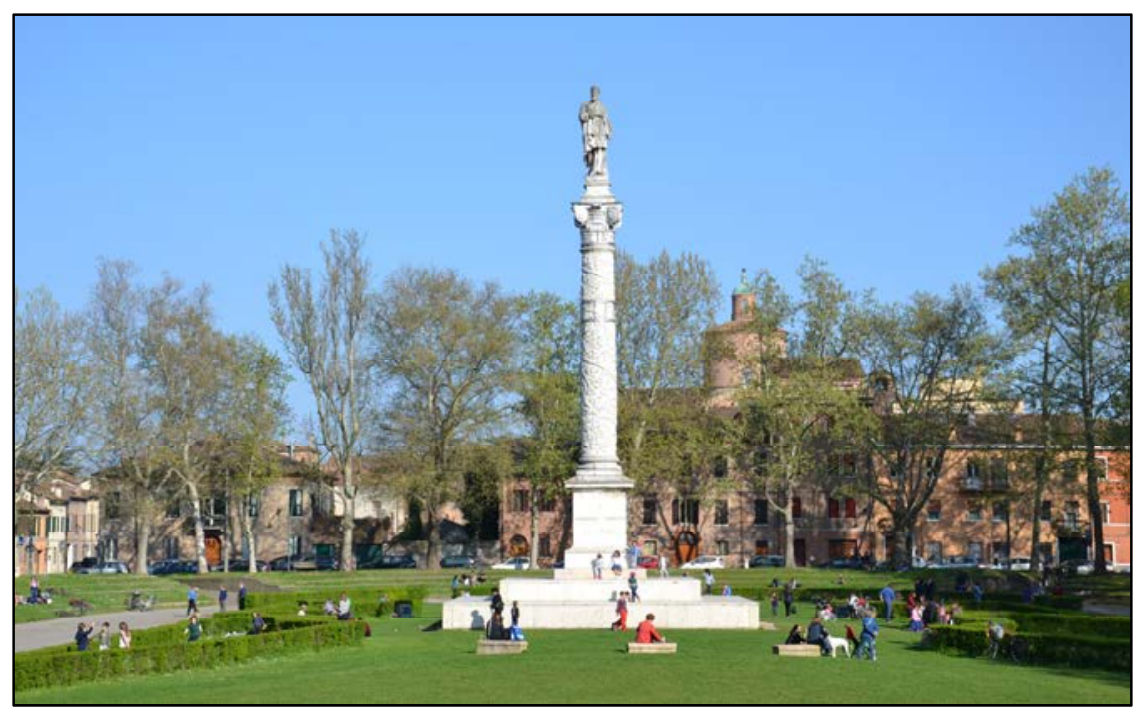

Figure 1: Monument of Ludovico Ariosto in Piazza Ariostea before the restoration works.

instead of what was the habit of previous political choices of the Italians courts to proceed with small, accidental building interventions in their cities. The opportunity to create new private building leaded the most influential people of the Court to start a competition against each other to show their taste and their competence in understanding and introducing the new way to built. This is the great work site where the provincial attitude towards architecture in Ferrara, start to see "shoots" of the classical architecture that, in the same years, was under theoretical and practical construction in more important courts like Florence and Rome. Understanding the whole complexity of the implications of the choices made at the end of the 15 th century is essential in order to create a conservation project respectful of one of the most important monuments of the renaissance in Ferrara.

The Duke Ercole I d'Este (1471-1505), in the end of 15th century, envisaged the creation of a new monument for the "Piazza Nova". This monument composed of two large columns on which an architrave would be placed to support an equestrian statue of himself (Fig. 2).

Only one of the two columns arrived in the piazza [2].

In a notarial deed of 10 January 1499 [3], master stonemason Antonio Di Gregorio, undertook to bring the large column positioned by the River Po to "Piazza Nova" and to arrange all necessary marble works within the year, following painter Ercole De Roberti's design, including the capital, architrave, frieze and cornice.

In a letter dated 19 September 1501, the Duke approached Cardinal Roano in Milan to request a design from Leonardo da Vinci [4] for the execution of the equestrian statue.

A document from 28 August 1503 clarifies that marble works were carried out around the column of "Piazza Nova" in part by master Antonio Di Gregorio, who died the same year. This document sets out the report signed by Biagio Rossetti, the Duke's engineer, regarding the stone works carried out on the column in 1503, and defines the sum that the heirs of the deceased master Antonio Di Gregorio should demand for the works that had been completed.

The inventory present in the workshop confirms these stone works; it was drawn up by Antonio Di Gregorio's son and reports that "unus capitellus magnus pro colona existente super platea nova" [5]. 


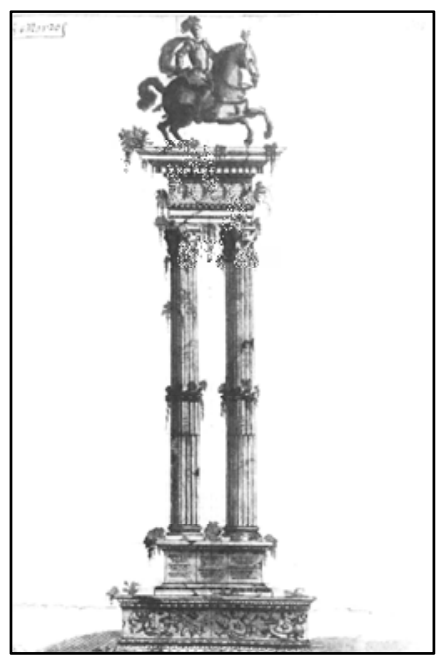

Figure 2: Anonymous designer, "Monumento equestre di Ercole I d'Este", 1603, Vatican Apostolic Library, manuscript. lat. 2774, c. 125r.

With the death of Duke Ercole I d'Este in 1505 and the rise into power of his son Alfonso I d'Este (1505-1534), the works were stopped, as testified by the historical maps from the end of the 16th and 17 th centuries where a rectangular pedestal with a column shaft lying at its feet were depicted in "Piazza Nova".

From the documents found at the Municipal Historical Archive (Municipal Historical Archive of Ferrara, "Serie Patrimoniale", Piazza Nuova, book 41, sheet 2), we learn that in 1604 they that in 1604 the column was to be raised, together with its capital, and a bronze statue of Clement VIII (1592-1605) placed on top. This project did not materialise either and it was not until 1675 that the decision was recorded in the documents (Municipal Historical Archive of Ferrara, "Serie Patrimoniale", Piazza Nuova, book 175, sheet 46; book 185, sheet 71 , book 188 , sheets $11,51,56,73$ ) to reduce the 16th century pedestal from a rectangular shape to a square, to modify its incisions and to define it proportionately with the erected column, on which would be placed the statue of Alessandro VII (1655-1667), Vice Legate in Ferrara from 1627 to 1632. It was also decided to alter the column shaft, where sculptor Cesare Mezzogori sculpted an oak branch to hide chips in the stone, while work was continued on the capital of the column by engraver Giovanni Comini (Municipal Historical Archive of Ferrara, "Serie Patrimoniale", Piazza Nuova, book 188, sheet 58).

The French invasion of 1796 led to the statue of the pope being removed from the top of the column in October of the same year and it was replaced by the Statue of Liberty, which was later removed following the Austrian invasion only three years later (1799). When the French regained possession of Ferrara, a statue of Napoleon was placed on top of the column on 31 May 1810 (statue sculpted in stone by the Bolognese sculptor Demaria). This was removed following the Austrian conquest of May 1814 and on that occasion, it was decided to change the name of the piazza, which had previously been named after the French emperor, to Piazza Ariostea. This decision was taken with the intention of dedicating the piazza to a Ferrarese personality distinguished in the arts and literature, who was separate from the political tensions and thus appreciated by the different governments that would follow over time. 
In 1833, after extensive debate, brothers Francesco and Mansueto Vidoni, stonemasons, were commissioned to create the statue of Ludovico Ariosto following Francesco Saraceni's design. The statue was erected on 25 November 1833.

When the left arm fell to the ground after a violent storm in June 1879, the Municipality sought to promote works on the statue and decided that the upper section should be reconstructed. They were carried out by sculptor Ambrogio Zuffi in 1881 (Municipal Historical Archive of Ferrara, 19th century correspondence, "Potenze - Monumenti", B31, file 2, sheet of 7 May 1881).

In April 1935, with the aim of adapting the piazza to the racing events of the Palio, the central part was dug out into a slight slope which uncovered part of the foundations of the Monument. The foundations were clad with white Verona stone slabs to form the first two high steps that are still visible today (Municipal Historical Archive of Ferrara, 20th century correspondence, "Strade e Fabbricati", B17, "Lavori di sistemazione di Pizza Ariostea 1935", sheet 31 January 1935).

Analysis of the documents found at the Municipal Historical Archive testifies to the numerous restoration works carried out on the whole of the monument, from the pedestal to the statue, from 1830 to 1881 (Municipal Historical Archive of Ferrara, 19th century correspondence, "Potenze - Monumenti", B31, file 2-3-1B, sheet from June 1830 to June 1881).

In order to complete documentary research carried out the metrological and proportional analysis. It consists of the architectural survey translation in to "piedi ferraresi", the measurement unit for buildings during the renaissance in Ferrara. This translation has lead to any important discovery: the proportions of the column are in correspondence with the criteria of the classic architecture as said in the contemporary literature. The proportion is calculated knowing how many times the measure of the cross section taken at the base of the shaft stays in the height of the column. In this case the proportion is 1:9 and it corresponds to architectural order called "composite". This means that the author of the drawing of the column, the painter Ercole de Roberti, was a cultivated artist. In fact Ercole de Roberti is the most important figure of painter and architect for the introduction of the classical language of the architecture in the Renaissance in Ferrara. This discovery told us the value until now unknown of the monument. We can add that the proportions of the column must not be modified by the restoration operations.

\section{THE “CRITICAL RESTORATION” PROJECT}

The historical/critical knowledge of the Monument of Ludovico Ariosto was the starting point for the restoration project. As per the tradition of "critical restoration" [6], the professionals involved considered the critical judgement behind the project choices from both a historical/aesthetic and structural point of view.

The first phase of the restoration project included analysis of documentary research and site investigations simultaneously. Firstly, historical research was carried out both by reading the published bibliography, cartography and iconography, and through archival research at the State, Municipal and Italian Heritage Office Archives.

The following were performed before proceeding with the works: site analysis using a drone and laser scanning to provide a 3D record, optical microscopy to define the various types of stone; diagnostic investigations using video-endoscopy, geo-radar and ultrasound to understand the structure of the monument; and accelerometer measurements for dynamic characterisation. Direct analysis led to the drafting of the architectural metric survey, photomaps, and cognitive and diagnostic analysis of the materials and structural parts. This 
allowed the drafting of the relief of the cracking pattern and analysis of the deterioration, both structurally and superficially.

The results of the documentary research and site investigations were compared and considered not only as a cognitive instrument but also as a reading of the character and specific values of the architecture. This aided the decision making processes, taking into consideration the current "culture of restoration".

The site investigations were carried out during the planning phase and revealed that the metal parts had suffered the greatest deterioration due to corrosion effects. The corrosion produce a significant increase of volume [7] that could be between 3 and 6 times the original volume [8] and this led to cracking and movements of stone parts. Although without measurements or monitoring in time, the corrosion was evidently more severe where coupled between two steel types. Indeed, two types of metal were used for reinforcement: normal steel, adopted in the past, and stainless steel, used in interventions that are more recent. The connection between these steels caused a cathodic oxidation effect which had accelerated and amplified the erosion of the traditional steel. These damaging mechanisms, triggered by metal oxidation, constitute, from a structural point of view, the most significant problem encountered in the whole monument, with the most compromised parts being in the podium of the statue and in the capital. The high chemical force developed by oxidation causes many fractures and cracks in monolithic bocks and produced many deformations in structures.

The statue of Ludovico Ariosto had particularly detached at the base due to the forward positioning of the bust. This problem had probably already been observed in the past considering the metal reinforcement to support the statue. However, today it appears to be ineffective and not well consolidated (Fig. 3).

The area of the podium, between the statue and the capital, is composed of several elements that constitute a wall of square stone elements which, following the deterioration of the connectors, have gradually become disconnected. Probably with the aim of reinforcing the various elements, a modern external metal support ring in stainless steel had been inserted and welded to the internal metal elements, causing accelerated oxidisation (Fig. 4). By analysing the cracks in the podium, an opening can be observed in the lesion, causing its upper part and the statue itself to incline. This phenomenon can be traced back to the jacking effect of the internally oxidised metal, particularly at the internal anchorage which has caused the discontinuity between the connectors to open up.

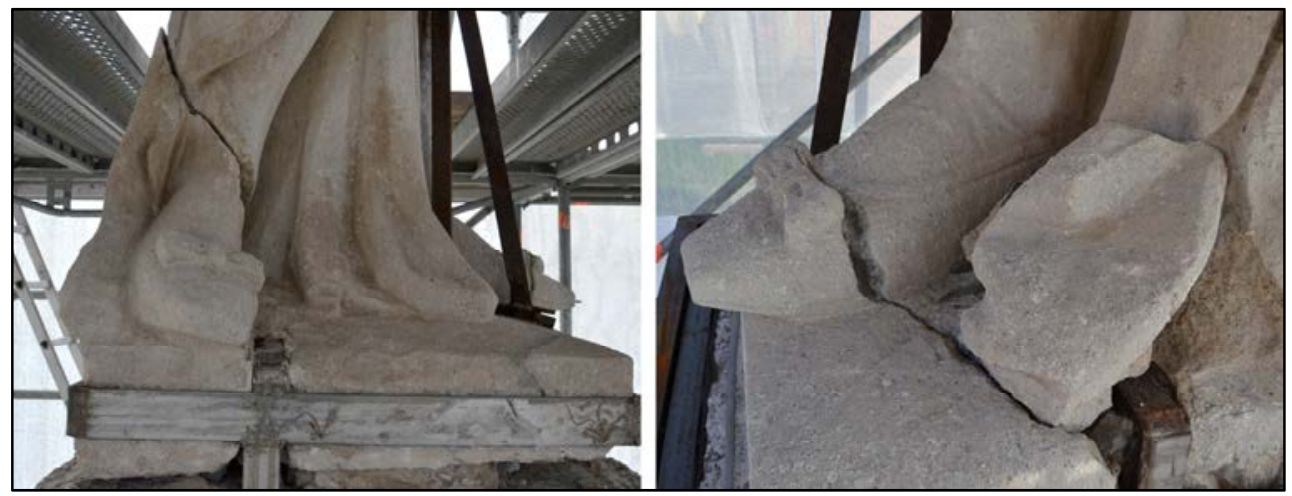

Figure 3: Statue of Ariosto disconnected at the base after cleaning the stone and removing the cement mortars. 


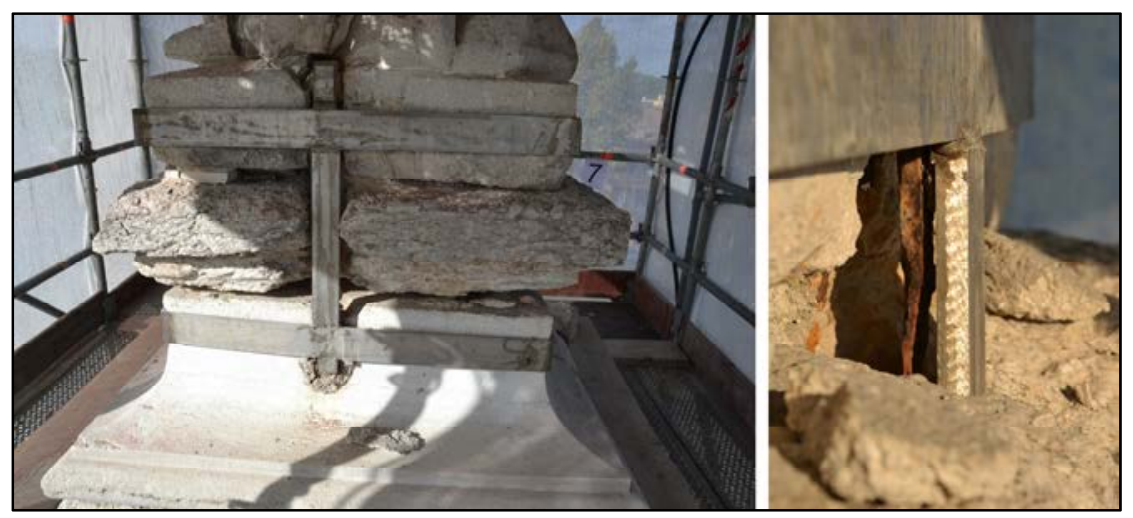

Figure 4: Podium of the statue. The external metal support ring in stainless steel has been welded to the damaged parts, accelerating oxidation.

The capital of the Ariostea column is made up of a series of four elements placed on top of each other, each of which constitutes various stone elements, positioned on the monolithic shaft (Fig. 5). Each stone element had detached with cracks a few centimetres wide (Fig. 6) due to the stone jacking caused by the expanding metal inside (Fig. 7).

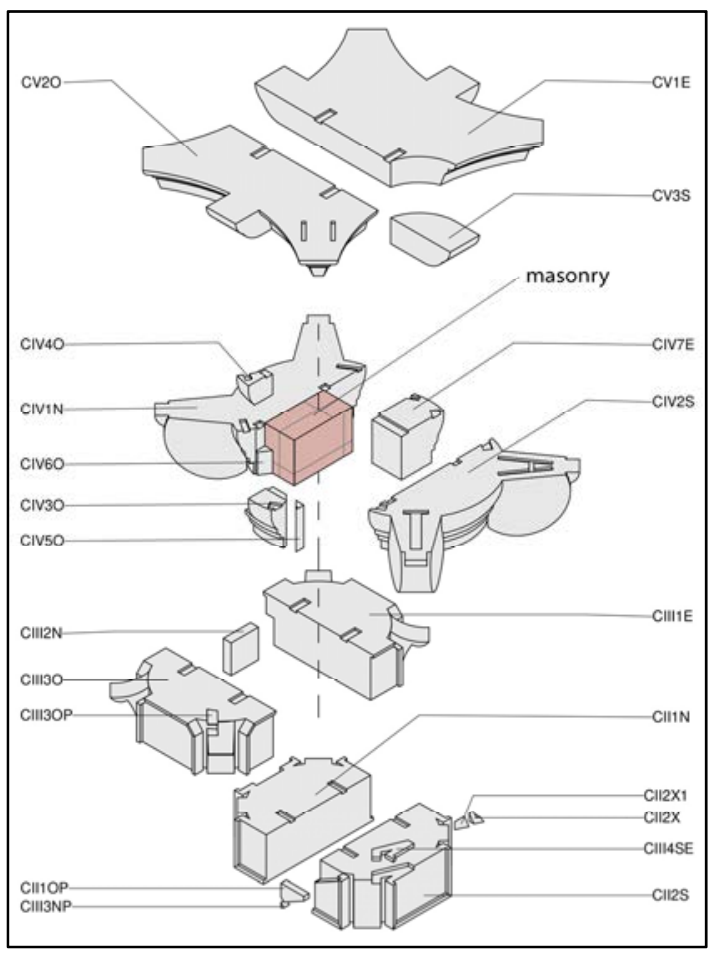

Figure 5: Exploded axonometric view of the capital drawn up following the dismantling of the various elements and preparation for their repositioning. 


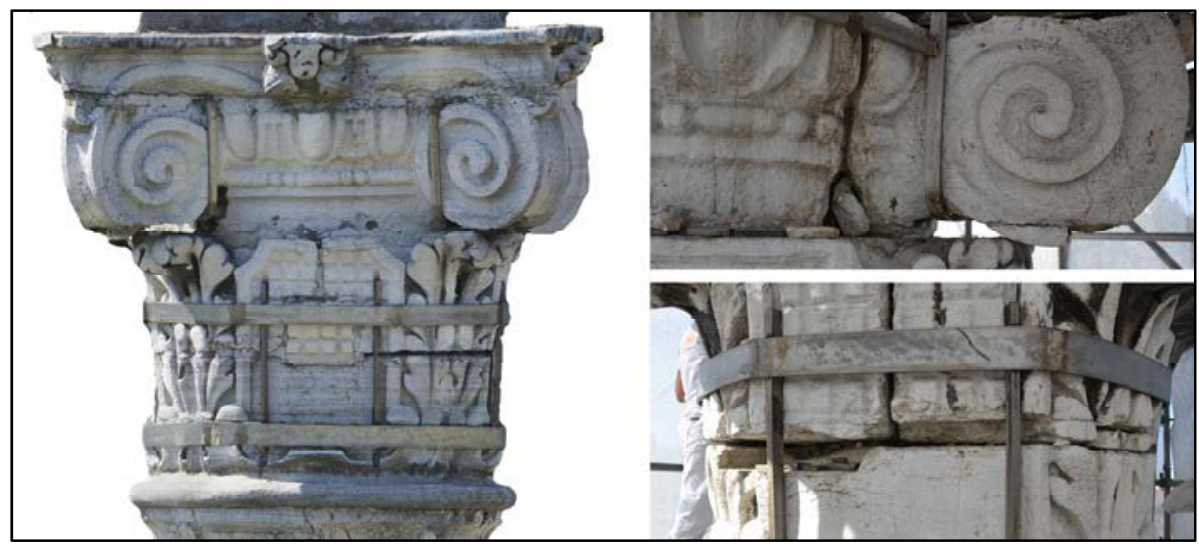

Figure 6: Capital of the column before the restoration works.

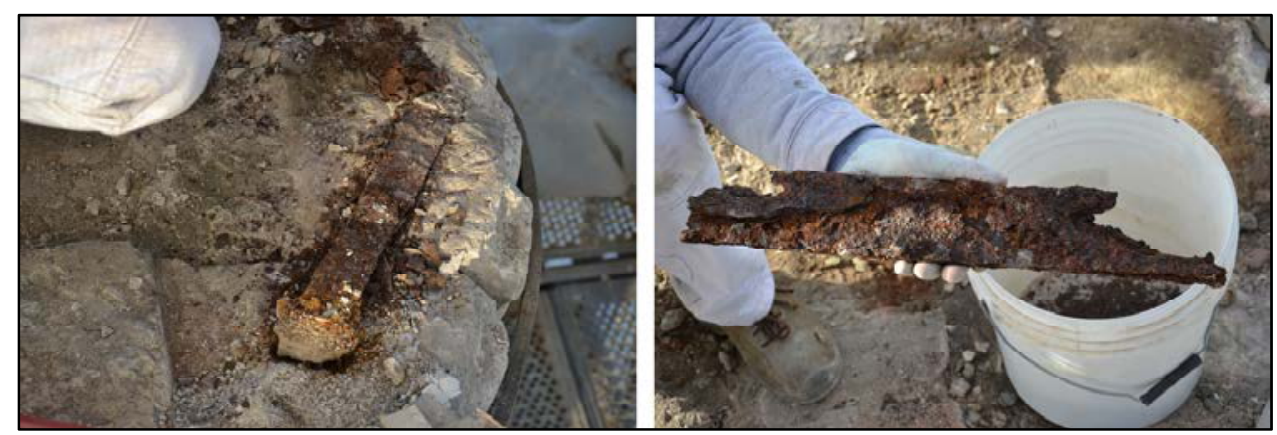

Figure 7: Oxidation of the internal fixtures between the parts which define the individual stone elements of the capital.

The composition of several blocks in the capital (Fig. 5) all connected by metallic elements subject to corrosions lead to three main problems: the loosing of resistance of the rusty connections, the fracturing of stone blocks due to chemical expansions, the uncontrolled displacements between blocks. These three effects provide respectively to: an unconnected structure, a fragmented capital and thus the risk of some blocks collapse, different inclinations and therefore movements of centroid positions.

Firsts ideas of interventions aimed at introducing substitutable metallic materials from outside because the substitution of such corroded elements in this work had been very expensive, it required the controlled disassembly and this might lead to damages on the structure, therefore, this substitution should be as much as possible avoided in the future. Those solutions were discarded because the loosing of the material was too relevant for a respectful restoration. In light of these observations, all the internal metal elements were replaced with new duplex stainless steel connectors of the same dimensions as the existing carbon steel ones and placed in the same positions (Fig. 8). The major initial cost of this special steel will be recovered in the major durability of the intervention moving forward the need for their substitution. Moreover, a consolidation with glass fibre reinforced bars was adopted to connect cracked blocks. 


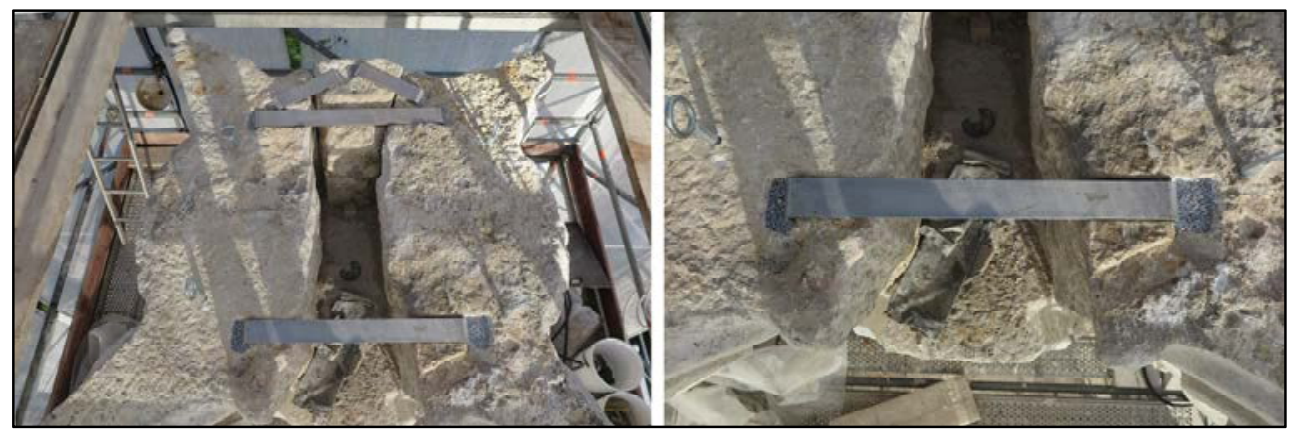

Figure 8: New cramps in duplex stainless steel connecting the various elements of the capital.

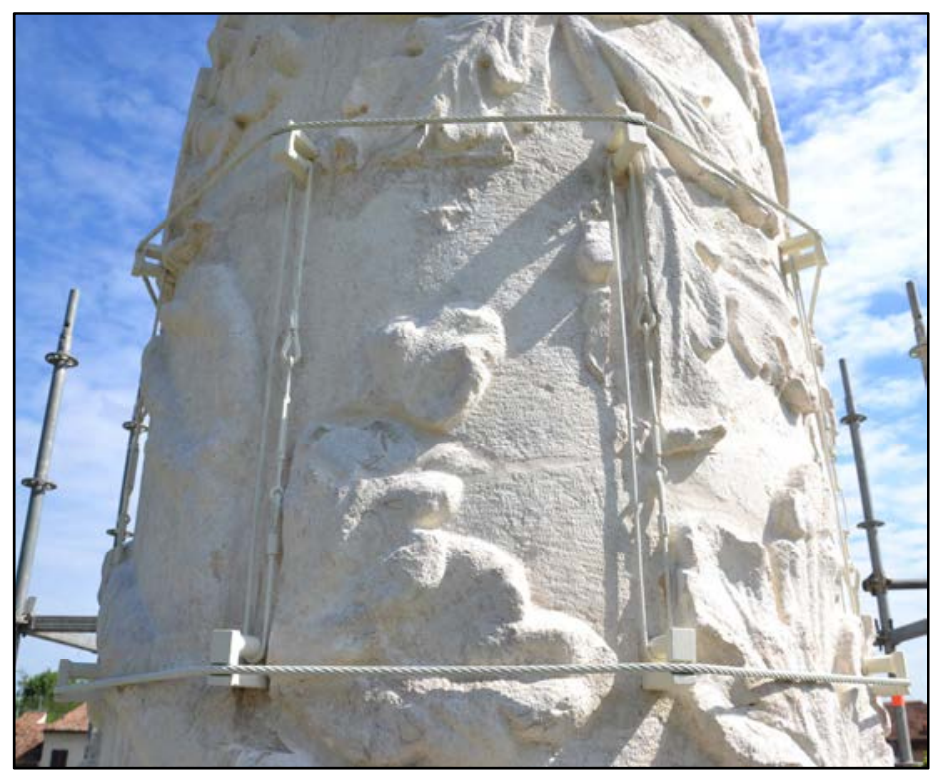

Figure 9: Stainless steel cables used to strengthen in flexure the shaft.

To be able to carry out this operation, it was necessary to lift the statue together with each stone element comprising the podium and the capital. This issue was the most complex one because of the lifted elements degradation and because, to prevent any loose of material, the lift framework was not inserted in the stone using a friction based application.

A second type of intervention was designed to prevent the column shaft from a possible failure due to a crack at about two third of the height. About sliding the crack does not overpass the entire cross-section and then it was not necessary to introduce connectors. In term of flexural behaviour a circular series of stainless steel cables inserted along existing grooves, replacing a previous intervention carried out in stainless steel externally (Fig. 9). In order to avoid the rising of bending moments on connectors two horizontal hooping were designed to counteract the flexural action. 
The metal cramps uniting the stone cladding on the cymatium of the pedestal of the column had suffered significant deterioration. As well as the restoration of the stone and its superficial treatment, the oxidised metal cramps were replaced with new ones in stainless steel, set and secured in molten lead.

The architectural surfaces were cleaned using biocides, clay poultices and manual techniques to remove superficial deposits, incrustations and the presence of biological staining. The incompatible elements were also removed (metal cramps and cement mortars) and the cracks and gaps were filled using special natural mortars mixed up on the site. They were then treated superficially with a thin coating (Fig. 10). As a final operation, the whole surface of the statue was treated with protective products, in particular to protect it against graffiti.

The monument presented widespread superficial deterioration caused by exposure to weather conditions and pollution. In particular, rainwater running from the top of the statue to the pedestal of the column had caused erosion, favouring the formation of biological patinas and the accretion of superficial deposits. There was a protective lead covering on the top of the capital, which was in such a poor condition that it had allowed rainwater to collect instead of letting it flow off the statue. In addition, the metal element, now oxidised and irregular, had altered the appearance of the top of the capital. The project involved removing the oxidised sheets and creating a more compatible system to allow rainwater to drain off the monument. A screed of breathable mortar was applied across the whole of the top of the capital with a slight inclination to help the rainwater run off and it was applied as thinly as possible so as not to alter the perception of the top of the capital. This was then covered in a sheet of lead.

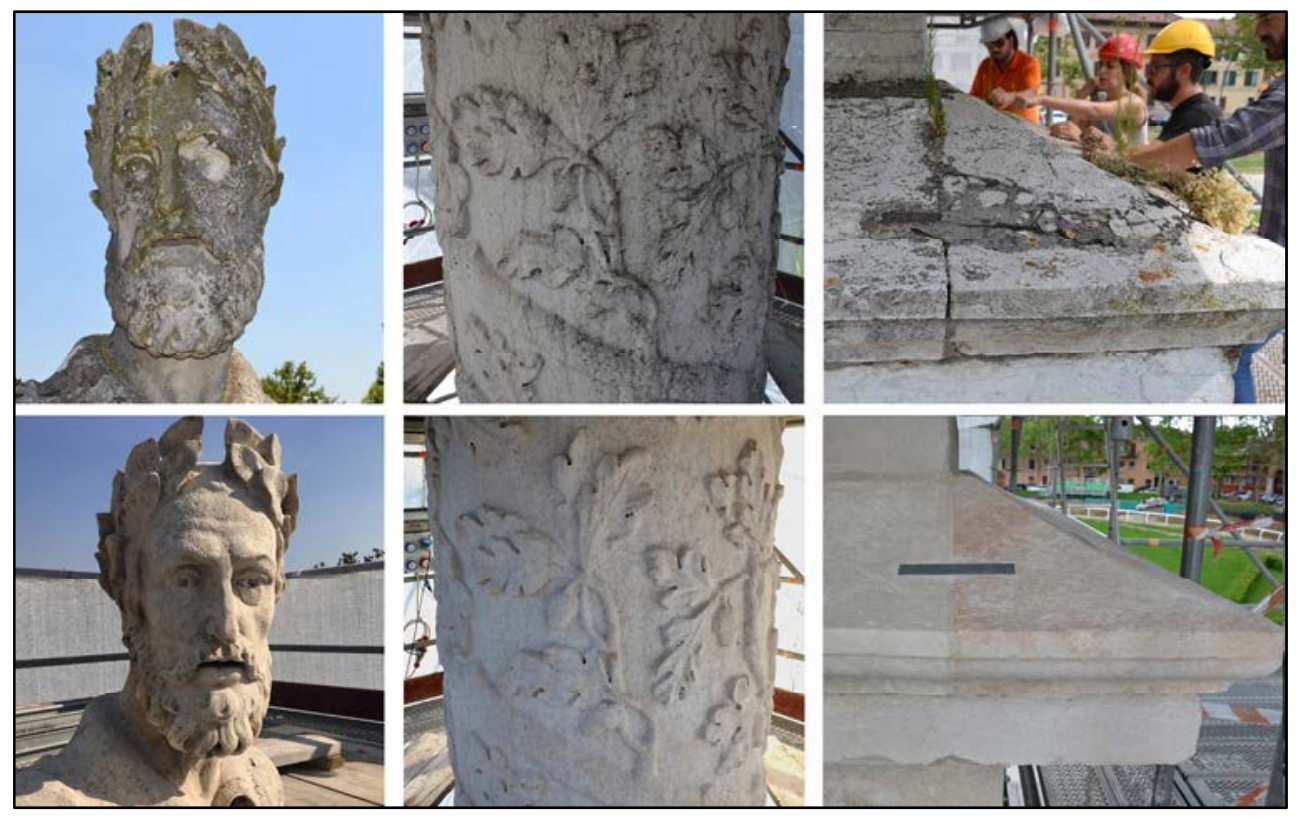

Figure 10: Operations to clean the surfaces of the statue, shaft and pedestal. 


\section{CONCLUSION}

The restoration project of the Monument of Ludovico Ariosto was configured and realised with a multi-disciplinary approach involving study, analysis and comparison between the professionals involved, municipal officials and officials from the Ministry of Cultural Heritage.

The objective of returning the monument to the community, which required both structural and superficial restoration, was pursued through a circular process of understanding and conservation, and was fulfilled based on critically evaluated choices to recuperate the monument's visual unity and consequent capacity to reveal itself in each and every one of its elements: "la esigibilità del monumento" (Fig. 11).

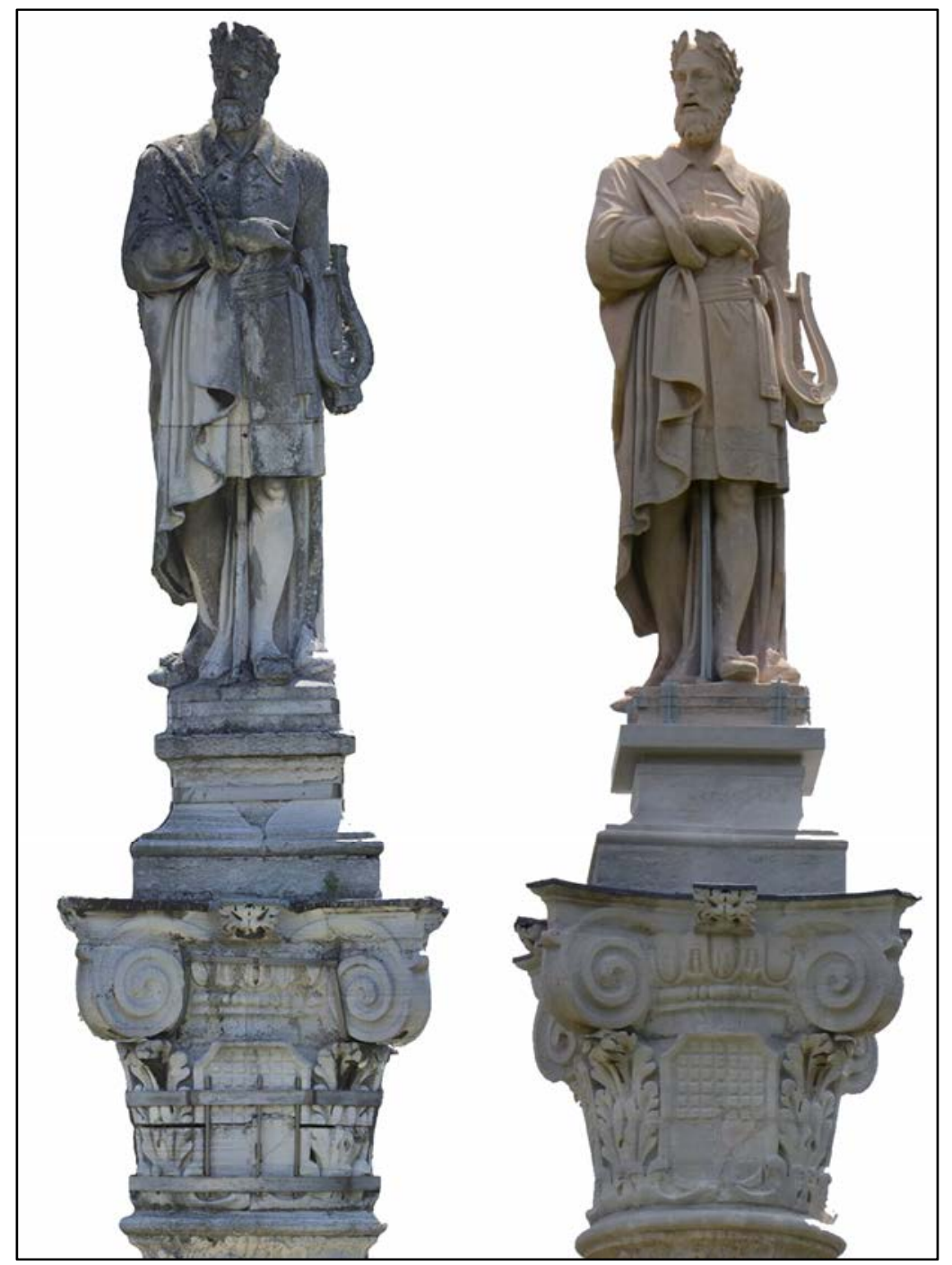

Figure 11: The capital, the podium and the statue before (left) of the restoration work and after (right). 


\section{REFERENCES}

[1] Zevi, B., Saper vedere l'urbanistica: Ferrara di Biagio Rossetti, la prima città moderna d'europa, Torino: Einaudi, 1971.

[2] Cittadella, L.N., Notizie amministrative, storiche, artistiche relative a Ferrara, Domenico Taddei, Ferrara, p. 23, 1868.

[3] Franceschini, A., Artisti a Ferrara in età umanistica e rinascimentale: testimoniante archivistiche, Volume II, Gabriele Corbo, Ferrara, p. 350, 1997.

[4] Campori, G., Nuovi documenti per la vita di Leonardo Da Vinci. Atti e Memorie delle R.R. Deputazioni di Storia Patria per le province modenesi e parmensi, Modena, pp. 46, 1865.

[5] Franceschini, A., Artisti a Ferrara in età umanistica e rinascimentale: testimoniante archivistiche, Volume II, Gabriele Corbo, Ferrara, p. 635, 1997.

[6] Carbonara, G., Restauro architettonico: principi e metodi, Architectural Book and Review, Roma, 2012.

[7] P. Pedeferri, Corrosione e Protezione dei Materiali Metallici, 2a edizione, CLUP, Milano, 1978.

[8] Takaya, S., Nakamura, S., Yamamoto, T. \& Miyagawa, T., Influence of steel corrosion products in concrete on crack opening weight loss of corrosion. Journal of Japan Society of Civil Engineers, 69(2), pp. 154-165, 2013. 